elevation of serum transaminases (aspartate aminotransferase (SGOT) and alanine aminotransferase (SGPT)) in patients taking propranolol has been reported by Stephen, but in sorne of his cases other factors could have been responsbile. We therefore consider it important to record our observation in a woman aged 69 years receiving propranolol $80 \mathrm{mg}$ daily.

She has been hypertensive for four years and the diagnosis of phaeochromocytoma was made on the basis of a rise in urinary catecholamine excretion. She was treated first with phenoxybenzamine $30 \mathrm{mg}$ daily for four weeks; the propranolol was added, first $40 \mathrm{mg}$ daily and after two weeks $80 \mathrm{mg}$ daily. She had previously been exposed to propranolol $40 \mathrm{mg}$ daily for one week at another hospital withou untoward effect. When receiving only digoxi (because of an episode of atrial flutter) and hydrochlorothiazide (for hypertension) with potassium supplements, transaminases, lactic dehydrogenase (LDH), and alkaline phosphatas were normal, and the addition of phenoxybenzamine $30 \mathrm{mg}$ daily for 3 weeks produced no change. Retesting four weeks after the addition of propranolol showed a rise in these enzymes in two samples drawn on different days (though one LDH sample was within normal limits) SGOT 275 and 275 I.U., LDH 395 and 185 I.U., alkaline phosphatase 275 and 300 I.U. On discontinuing propranolol while continuing othe medications serum enzymes returned to normal.

She had longstanding minimal ankle oedema. probably due to impaired venous drainage, and there were no other features of heart failure. Moreover no other evidence of impairment of liver function was detected, including tests for Australia antigen before, during, or after the period of raised enzymes.

The temporal relationship of these abnormalities to propranolol is very suggestive of a causal effect. We did not feel justified in re-exposing her to the drug to prove this, as the phaeochromocytoma has now been removed and she has no furthe need for propranolol.

Since propranolol is a very useful drug in several conditions and this side effect appears to be uncommon and reversible we do not recommend that its use should be restricted because of it. Nevertheless, it would seem prudent to check serum enzymes from time to time during therapy. We are, etc.,

ROBERT WILKINSON JOHN A. LUETSCHER ROBERT H. GOLDMAN

Department of Medicine, Stanford University School of Medicine Palo Alto, California, U.S.A.

1 Waal, H. I. Clinical Pharmacology and Thera peutics, $1966,7,588$

Richards, F. A., American fournal of Cardiology, $1966,18,384$

Mauck, H. P. W.. Freund, J., Grear, A. S. $1968,37.534$.

4 Frohlieh, E. D., Tarazi, R. C., Dustan, H.P. and Page, I. H., Circulation, $1968,37,417$ Stephen, S. A., American fournal of Cardiology,

\section{Overdosage of Tetracosactrin in Rheumatoid Arthritis}

SIR,-Dr. F. Dudley Hart and others (17 April, p. 165) draw attention to the problem of overdosage of synthetic corticotrophin, tetracosactrin. They state that the preparation they use contains $1 \mathrm{mg}$ of tetracosactrin in $1 \mathrm{ml}$ of a zinc phosphate complex. Recommending smaller doses they end their letter with the plea "the availability of a more dilute solution would make the injection of these small doses somewhat easier".

Cortrosyn Depot is presented in the more dilute solution of $0.5 \mathrm{mg}$ tetracosactrin in $1 \mathrm{ml}$ of zinc salt complex, and we find that it is used by those who, like the Westminster group, require to use doses that ar regularly below $0.5 \mathrm{mg}$ tetracosactrin.-I am, etc.,

A. F. TAYLOR

Morden, Surrey Organon Laboratories Ltd.

\section{Gold for Rheumatoid Arthritis}

SIR,-I have read with interest your leading article (27 February, p. 471) and also Dr. H. J. A. Richards's letter (p. 504). In both instances there would appear to be an important omission-namely, the time factor.

For a period of 18 years I had occasion to treat a considerable number of patients with gold, and there were never (and I would stress the word never) any significant side effects. This could, of course, be relative to the size of the dose, but I ascribe it to the fact that after each series of 12 weekly doses the patient was required to have eight weeks rest from the treatment. For a time blood and urine tests were made, but the former were ultimately omitted as being unnecessary.-I am, etc.,

\section{F. E. Graham-Bonnalie}

Edinburgh 9

\section{Dyspareunia}

SIR,-In Mr. W. T. Fullerton's article (3 April, p. 31) on "Dyspareunia" although infection was mentioned as being a cause of this disorder I thought its importance was underemphasized. In younger women, especially in large cities, surely such conditions as trichomoniasis, candidiasis, and herpes labialis are often more importan causes of dyspareunia than less frequently seen pelvic abnormalities.

The patient with trichomoniasis often has an exquisitely tender vagina and it is quite obvious how painful this. Herpes labialis caused by herpes virus hominis must be cause of dyspareunia.

The average specimen of vaginal discharge taken in a surgery and sent for laboratory examination, I submit, is a useless investigation unless taken under very careful conditions. In most cases the possibility of gonococcal infection will be overlooked-and poorly treated-with disastrous medical and legal complications later on.-I am, etc.

\section{Michael A. WaUgh}

Department of Venereology

West London Hospital,

SIR,-Mr. W. J. Fullerton (3 April, p. 31) is to be congratulated on his excellent and emphatic article on dyspareunia in gynaecology in general practice. Many practitioners are not aware of the problems associated with "failure of lubrication." However, in addition there may be a iatrogenic factor brough about by the anti-oestrogenic effect of some of the oral contraceptive preparations. This is particularly prone to develop in those women whose periods tend to be scantier than most or in those whose libido is only fair. This problem especially tends to occur with the formulations containing a higher content of norethisterone and its acetate.

A doctor who is aware of this possibility might often prevent this adverse effect of hormonal contraception by a judicious choice of brand of contraceptive. This problem can also present as recurrent and intractable monilial infection. Furthermore, it would appear that the anti-oestrogenic effect of some of the progestagens in the oral contraceptives might contribute significantly to the alleged disturbances of libido per se, in addition to their "drying" effect on the vaginal secretions. Once these undesirable effects are recognized, they can be dealt with by changing the formulation to a preparation which is more oestrogenic in action or even altering the method of contraception. -I am, etc.

University of Southampton

Max Elstein

\section{Gastrointestinal Bleeding}

SIR,-Your leading article entitled "Pharmacological Control of Upper Gastrointestinal Bleeding" (13 Manch, p. 569) betrayed a rather naive approach to the complexities of the effects of drugs on the gastrointestinal circulation. Reliable data on man are lacking but some indication of the problems may be gained from animal experiments. In this context studies on the dogs ${ }^{1}$ are of questionable value, since the easily-induced constriction of the canine hepatic veins produces responses which are not analogous to those in the human. ${ }^{2}$ For this reason, the splanchnic vascular bed of the cat has received intensive investigation. These studies indicate several objections to the infusion of adrenaline and propranolol after haemorrhage from the gastrointestinal tract even if one makes the big assumption that intestinal vasoconstriction reduces bleeding from a ruptured artery.

Stimulation of the alpha-adrenergic receptors in the intestinal vascular bed causes a brief vasoconstriction followed by autoregulatory escape during which intestinal flow recovers to approximately the preinfusion level. ${ }^{3-5}$ This escape occurs within 1-2 minutes and is not blocked by propranolol. ${ }^{6}$ Adrenaline itself causes dilatation of the intestinal and splenic arterioles, ${ }^{7-8}$ and if the beta-receptors were not adequately blocked by the propranolol a sizeable vasodilatation would occur. Full blockade of the intestinal beta-receptors must inevitably be accompanied by more wide-spread effects and, in particular, by an impaired cardiac response to haemorrhage.

Passage of the mixture into the portal blood would probably cause an elevation of portal venous pressure by constriction of the portal radicles and a reduction in hepatic arterial flow. ${ }^{2} 9$ Vasopressin, on the other hand, causes maintained constriction of the intestinal and splenic arterioles and no constriction or even a dilatation of the hepatic arterial bed. 5810 Preservation of flow through the hepatic artery may help to prevent some of the metabolic consequences of haemorrhage.

In conclusion, it appears from animal experiments that local infusion of adrenaline and propranolol would produce a variety of 
responses, some of which might promote either heamorrhage or its deleterious effects. Clearly, these data should be studied before a new therapeutic regimen is tested in man. Recent work suggests that after haemorrhage Nature herself cannot constrict the intestinal bed by sympathetic means and has resorted to the use of vasopressin. 1112 I am, etc.,

\section{R. D. Stark}

Department of Medicine,

Queen Eliza

1 Rösch, J., et al., Gastroenterology, 1970, 59, 341. 2 Greenway, C. V., and Stark, R. D., Physiological
Reviews, 1971, 51, 23.
3 Folkow, B., Lewis, D. H., Lundgren

ander, B., Lewis, D. H., Lundgren. O., Mellander, S., and Wallentin,

- Folkow, B., Gastroenterology, $1967,52,423$ Folkow, B., Gastroenterology, 1967, 52, 423.
Dresel, P., and Wallentin, I., Acta Physiologica
Scandinavica, 1966, 66, 427.

Mellander, S., and Johansson, B., Pharmacological Reviews, 1968, 20, 117

Greenway, C. V., and Lawson, A. E., Canatian
fournal of Physiology and Pharmacology, 1968,

8 Greenway, C. V., and Stark, R. D., British fournal of Pharmacology, 1970, 38, 583.

S., fou, C. V., Lawson, A. E., and Mellander, Cohen, M. M., Sitar, D, S.. McNeill, J. Greenway, C. V., American fournal of Physiology, 1970, $218,1704$.

McNeill, J.'R., Stark, R. D., and Greenway, Stark, $R$.

C. Y.. American foumal of Physiology, in press.

\section{Beriberi in Bethnal Green}

SIR,-Dr. M. W. P. Carney's account of two cases of beriberi (10 April, p. 109) prompts me to report another case recently seen.

A woodmill worker, aged 64 , presented to his general practitioner with a three weeks' history of shortness of breath and purulent cough. He was noted to be cyanosed and to have heart failure and was admitted on 1 March 1971 to Bethnal Green Hospital. On admission his jugular venous pressure was elevated to the angle of the jaw, he had slight ankle oedema, and a good volume pulse. The chest showed evidence of extensive infection and the liver was enlarged four finger breadths. A diagnosis of acute on chronic bronchitis with cor pulmonale was made and he was treated with tetracycline and cyclopenthinzide (Navidrex K).

His infection rapidly improved, but the oedema became progressively more severe and he gained $\frac{1}{2}$ stone $(3 \cdot 2 \mathrm{~kg})$ in weight. His diuretics were changed to frusemide, $80 \mathrm{mg}$ daily, and digoxin was added. There was no obvious improvement and spironolactone was added. There was still no improvement and therefore the possibility of beriberi was considered. He was given thiamine, $25 \mathrm{mg}$ intramuscularly, followed by Parentrovite, $1+2$ intravenously. This produced a startling diuresis of 6 litres over the next two days and in the course of a week he lost a stone $(6.4 \mathrm{~kg})$ on vitamin supplements and digoxin alone.

In retrospect we learnt that this man was a heavy drinker and that he was single and lived with his brother. There was no evidence of peripheral neuropathy and pyruvate levels were not performed. However, the dramatic response to thiamine in severe refractory oedema, the known poor diet, and the finding of a mild iron deficiency anaemia point very strongly to the diagnosis. This again underlines the importance of being aware that this disease is likely to occur in at-risk groups.-I am, etc.,

A. K. Clarke Bethnal Green Hospital, London E.2

\section{Shut Away}

SIR,-You are to be congratulated on the timely leading article "Shut Away" (17 April, p. 119), which presented a comprehensive and balanced sympathetic understanding of the problems of hospitals for the mentally handicapped.

The general response to the unhappy state of affairs which is being repeatedly exposed in these hospitals is predictable. Firstly there is the rush to find a scapegoat, and doctors, nurses, and administrators are sitting targets. Secondly, there is the search for a magic formula which will solve all the problems. The clamour for the appointment of a "health commissioner," another official to chase officialdom, seems strange in a country which has usually shown a suspicious disrespect for red tape. A health commissioner, however, highly paid, is not by dint of his ofice necessarily any more of a paragon of impartiality, knowledge, integrity, and sympathy than any other government officer or department. A health commissioner cannot himself press people to become nurses of the mentally handicapped. He cannot compel citizens to be voluntary workers in hospitals and he cannot provide money which is not there. If hospitals for the mentally handicapped are overcrowded can a health commissioner ask relatives to take patients home, or order them to visit their less fortunate kin in hospital if they do not wish to do so? Will a health commissioner direct local authorities to take patients into the community which has no facilities for them?

The danger in the appointment of a health commissioner is that it will be another mechanism by which the community can escape from its responsibilities to the mentally handicapped. It is an easy manoeuvre to solve the public's conscience in the face of a problem about which so many people still prefer not to know.-I am, etc.,

Meanwood Park Hospital,

D. A. SPENCER

Leeds 6

\section{Bacteriuria Again}

SIR,-Your leading article (13 February, p. 361) suggests that gentamicin can cause vestibular damage "even when serum levels are within what is considered to be the safe range."

It is our duty to base dosage recommendations on clinical experience. Such experience has shown that labyrinthine damage occurs only if the blood level exceeds $10 \mu \mathrm{g} / \mathrm{ml} .^{1}$ In the few cases of labyrinthine damage which have been reported to us the blood level was in excess of this limit because of significant impairment of renal function or unnecessarily high or prolonged dosage in patients with normal renal function. It is perhaps noteworthy that a level of $10 \mu \mathrm{g} / \mathrm{ml}$ has frequently been exceeded without toxic effects. In return, it is the duty of clinicians to report clinical details if they have found that lower concentrations have produced vestibular damage in order that recommended limits are indeed safe. Reports so far received certainly do not warrant the comment that "gentamicin is notoriously toxic," and the evidence justifies our current recommendation which may even prove to be conservative.-I am, etc.,

Norman O. Eve Director of Medical Services,
Roussel Laboratories Ltd.

Wembley Park

Middlesex

Garrod, L. P., and O'Grady, F., Antibiotic and

Chemotherapy, Edinburgh, Livingstone, 1971 .

SIR,-In your leading article "Bacteriuria Again" (13 February, p. 361) the statement that generation can cause vestibular damage "even when serum levels are within what is considered to be the safe range" requires further examination.

It has been advised by the manufacturers that a serum gentamicin level of $10 \mu \mathrm{g} / \mathrm{ml}$ should not be exceeded. Serum levels of less than $10 \mu \mathrm{g} / \mathrm{ml}$ have occasionally been reported in patients with ototoxicity during treatment with gentamicin, but these may not necessarily have been the highest serum concentrations achieved. It is likely that peak serum levels higher than $10 \mu \mathrm{g} / \mathrm{ml}$ may well have occurred following injection in these patients. Patients with ototoxicity with normal renal function have in retrospect had grossly excessive dosage, or have been assumed wrongly to have normal renal function. More than 50 of the few reported patients with ototoxicity, due to gentamicin therapy have had impaired renal function. ${ }^{1}$ Unfortunately, insufficient data are provided to allow estimation of the probable serum levels obtained with the dose regimen employed in these patients, but accumulation to high serum and tissue levels probably occurred. Since using the previously reported dose regimen designed to avoid this occurence $^{2}$ I have not encountered any instance of ototoxicity.

A large number of patients have received gentamicin therapy, usually for clinically significant urinary tract infections with multiresistant organisms including Pseudomonas aeruginosa and often in the presence of impaired renal function. It seems probable that ototoxicity due to gentamicin in man is dose related, and at the present time there is, to my knowledge, no evidence to suggest that valid peak serum gentamicin levels of less than $10 \mu \mathrm{g} / \mathrm{ml}$ have been associated with permanent vestibular dysfunction.-I am, etc., Department of Urology,

J. C. Gingell Bristol 1 Jackson, G. G., Practitioner, 1967, 198. 855.
2 Gingell, J. C., and Waterworth, P. M., British
Medical fournal, 1968, 2, 19.

\section{Unnecessary X-rays}

SIR,-Mr. David F. Thomas (10 April, p. 105) seeks support in condemning the submission of patients to indiscriminate and unnecessary $x$-ray. There can be little doubt that too many $x$-rays are ordered in casualty 